\title{
Effects of chlorine and potassium mineral nutrition on the leaf morphology of the PB 121 hybrid coconut palm (Malayan Yellow Dwarf x West African Tall)
}

\author{
I. Mialet-Serra ${ }^{1}$ and X. Bonneau ${ }^{2}$
}

\begin{abstract}
The effects of chlorine and potassium on the leaf morphology of 6-year-old PB 121 hybrid coconut palms were studied in 1995 and 1996 in southern Lampung (South Sumatra, Indonesia). The parameters considered were frond and leaflet size (length, maximum width, area) and their number. Chlorine and potassium had an exclusive effect on leaflet size, increasing their area. Potassium primarily affected petiole length, hence total frond length. Synergy between these two ions only occurred for the number of leaflets. Chlorine and potassium acted independently on stem diameter and synergistically on height. Coconut palms receiving potassium or chlorine had significantly more voluminous leaf crowns. As time went by, this phenomenon increased despite constant monthly leaf emission. In a situation of equilibrium, the much larger mean crown area and leaf area index of coconuts receiving chlorine and potassium augured well for an earlier start to bearing and higher nut yields.
\end{abstract}

Keywords: Cocos nucifera L., chlorine effect, potassium effect and leaf morphology.

${ }^{1}$ CIRAD/AMIS, Programme Agronomie, TA 40/01, Avenue Agropolis, 34398 Montpellier cedex 5, France

${ }^{2}$ CIRAD/CP, Programme Cocotier, Avenue Agropolis, 34398 Montpellier cedex 5, France 


\section{Introduction}

Coconut cultivation is widespread throughout the humid tropics, covering 10 to 11 million hectares. Southeast Asia and Pacific Islands alone account for $94 \%$ of these areas. The plantings are mainly smallholdings of no more than a few hectares. Coconut is traditionally grown along coastal strips or nearby, suggesting that coconut palms are well acclimated to the proximity of the sea.

Coconut is a monocotyledon whose single axis grows in an indeterminate way and whose terminal meristem continually produces leaves and inflorescences. Morphological and other biological criteria enable a distinction to be made between two main groups of individuals: Talls that are hardy and low yielding and Dwarfs, which are early yielder. The PB 121 hybrid is the result of crossing a Malayan Yellow Dwarf female parent with a West African Tall male parent. It combines perfectly the qualities of both parents: earliness and hardiness, which is reflected in a high yields and adaptability to different environments (Nucé de Lamothe et al., 1985). This material lends itself well to crop extension to inland zones. However, as water availability in the soil is frequently a limiting factor, even with improved planting material, water management has to be optimized. Agronomists started investigating this problem in the 1950s. Attention was first paid to the potassium ion and its effect on coconut palm growth, right from an early age, was very quickly recognized. However, its presence alone could not suffice under water stress conditions. Agronomists then looked at the chlorine ion. They found that when it was combined with potassium it played a synergistic role in growth and yields of coconuts, increasing them, and had an exclusive role with an increase of resistance to water stress (Ollagnier et al., 1983; Ollagnier, 1985). This second point was examined by Braconnier (1988) in a study on the physiology of chlorine nutrition in coconut palms. His work provided a clearer picture of the physiological role of the $\mathrm{Cl}^{-}$, showing that this ion was involved at two levels: in stomatal control mechanisms and osmotic phenomena. Osmotic adjustment in response to water stress occurs well before stomatal closure and helps to maintain cell turgor, improving cell growth and stomatal opening, among other things. Although gas exchanges are reduced, they are maintained at a satisfactory level, with continuous penetration of $\mathrm{CO}_{2}$ feeding the photosynthesis processes. As the effects of chlorine and potassium on the growth process are undeniable, the following study sets out to analyze treatments with or without chlorine and potassium, the dissociated effects of each of these two nutrients and their interaction on morphological characters primarily concerning the foliage in PB 121 hybrids, on different scales (organ, plant, and plot).

\section{Materials and methods}

\section{Trial site}

The plantation covers 6,000 ha in Lampung province in South Sumatra, Indonesia $\left(4^{\circ} 38 \mathrm{~S}\right.$, $\left.105^{\circ} 15 \mathrm{E}\right)$. Major climatic characteristics include two successive seasons: a rainy season from November to April and a dry season from May to November. Water deficits from one year to the next vary in degree and are sometimes considerable like in 1994 (Table 1).

The soil called locally red-yellow podzolic is of a formalistic type with a podzolic tendency. The texture of upper horizons is sandy-clayey with an increase of clay with depth (Table 2). The organic matter in topsoil is very satisfactory, greater than $2 \%$. The $\mathrm{C}$ : $\mathrm{N}$ is low, indicating a good rate of mineralization. The $\mathrm{pH}$ is slightly acidic. Exchangeable P content is low, but we know by experience that it is not limitation for growing coconut in this type of soil. The cation exchange capacity is low, with a high proportion of exchangeable $\mathrm{Al}$ (without any ill effects on the coconut in this type of soil). Exchangeable $\mathrm{K}$ content is low but $\mathrm{K}: \mathrm{Mg}$ ratio is satisfactory. The chemical properties of this soil are suitable for coconut farming. The limiting factor is physical with a highly compacted and very strongly cemented accumulation, locally called "hardpan" 
which appears between 100 and $150 \mathrm{~cm}$ depth and strongly limits the soil water reserve.

\section{Experimental design}

The original fertilizer trial, set up in December 1989, was a factorial with 3 factors (i.e. $\mathrm{K}, \mathrm{Mg}$ and $\mathrm{Cl}$ ) at 3 levels (i.e. 0,1 or 2 $\mathrm{kg} / \mathrm{tree}^{-1} / \mathrm{year}^{-1}$ ), with one subdivision at two levels (i.e. PB 121 and PB 111 hybrids) and one replicate. So it was composed of 54 elementary plots with 36 coconut palms of which 16 were used (4 lines of 4). The total surface of the trial was 12.2 ha. The planting density was $160 /$ trees $/ \mathrm{ha}^{-1}$. The fertilizers used were $\mathrm{K}_{2} \mathrm{SO}_{4}$ at $50 \% \mathrm{~K}_{2} \mathrm{O}$, dolomite at $18 \% \mathrm{Mg} \mathrm{O}$ and $\mathrm{Na} \mathrm{Cl}$ at $55 \% \mathrm{Cl}$. They were applied twice a year, in May and November during the three first years and then once a year in May.

For our experiment (between July 1995 and November 1996), only four treatments at 2 factors and 2 levels were studied (Table 3); treatment $\mathrm{K} 2 \mathrm{Cl} 2$ with application of both $\mathrm{K}$ and $\mathrm{Cl}, \mathrm{K} 2 \mathrm{Cl} 0$ and $\mathrm{K} 0 \mathrm{Cl} 2$, with only $\mathrm{K}$ or $\mathrm{Cl}$ application respectively, and lastly the control treatment $\mathrm{K} 0 \mathrm{Cl} 0$. The effects on $5 \mathrm{~PB} 121$ hybrids were studied.

\section{Description of the coconut palms}

The leaf structure was described at an organ scale with a description of the leaflets and fronds, at a plant scale with a description of the stem and the crown, and lastly at a plot scale through an estimation of the leaf area index.

\section{Description of the leaflets}

In July 1995, one frond ${ }^{1}$ for each of the 5 palms per treatment was chosen. The total length of 10 to 16 leaflets on each frond was measured,

\footnotetext{
${ }^{1}$ The rank of each sampled fronds varied between 10 and 17. They are similar to rank 14 , which is usually considered as the reference rank in agronomy. It is in fact from that frond that samples are taken for leaf analysis. They are adult tissue, in equilibrium, i.e. neither too young nor too old, hence representative of the average nutritional status of the palm (Bonneau, 1998).
}

with the width every $10 \mathrm{~cm}$. These leaflets were positioned regularly, every $40 \mathrm{~cm}$ on average, along the rachis and thereby satisfactorily reflected the evolution of sizes.

\section{Description of the fronds}

The lengths of the petioles ${ }^{2}$ and rachises $^{3}$ were measured on each of the previous 5 green fronds for each treatment. The total number of leaflets per frond was also counted at the same time. Once a month, from March to November 1996, old dry fronds were collected and described as above.

\section{Overall description}

The stem height and diameter (at $1 \mathrm{~m}$ from the ground) were measured in July 1995. The number of functional fronds (counted from the youngest, unfurled rank 1 frond) was recorded every month, from July 1995 to October 1996.

\section{Method of estimating areas and the leaf area index}

\section{Estimating the area of a leaflet $A_{l}$}

Depending on its total length, each leaflet was cut into $n$ trapeziums. The area of a leaflet was calculated from the sum of the areas of the n1 trapeziums presenting a heigth of $10 \mathrm{~cm}$ and of the nth terminal triangle (Tailliez et al., 1992). The area of a leaflet was therefore equal to:

$$
\begin{aligned}
& \mathrm{A}_{1}=\left(\mathrm{l}_{0}+\mathrm{l}_{1}\right) / 2 \times 10+\left(\mathrm{l}_{1}+\mathrm{l}_{2}\right) / 2 \times 10+\ldots \ldots\left(\mathrm{l}_{\mathrm{n}-1}+\right. \\
& \left.\mathrm{l}_{\mathrm{n}}\right) / 2 \times \mathrm{L}_{\mathrm{n}} \\
& \mathrm{l}_{0}, \mathrm{l}_{1} \ldots . \mathrm{l}_{\mathrm{n}}=\text { widths in } \mathrm{cm} \\
& \mathrm{L}_{\mathrm{n}}=\text { the length of a terminal triangle in } \mathrm{cm} \\
& \mathrm{A}_{1}=\text { the area of the leaflet in } \mathrm{cm}^{2} .
\end{aligned}
$$

\footnotetext{
${ }^{2}$ The petiole is measured from the proximal part of the frond up to the point of insertion of the first leaflets.

${ }^{3}$ The rachis is the part of the frond on which the leaflets are inserted.
} 
Table 1. Monthly climatic data for Gunung Batin in different years

\begin{tabular}{|l|rrr|rrr|rrr|}
\hline & \multicolumn{3}{|c|}{ Rainy fall $(\mathrm{mm})$} & \multicolumn{3}{|c|}{ Evaporation $(\mathrm{mm})$} & \multicolumn{3}{c|}{ Water deficit (mm) } \\
\hline Month & 1994 & 1995 & 1996 & 1994 & 1995 & 1996 & 1994 & 1995 & 1996 \\
\hline January & 392 & 391 & 292 & 146 & 167 & 121 & 0 & 0 & 0 \\
February & 262 & 264 & 299 & 119 & 128 & 115 & 0 & 0 & 0 \\
March & 511 & 339 & 458 & 154 & 111 & 126 & 0 & 0 & 0 \\
April & 316 & 362 & 241 & 132 & 127 & 108 & 0 & 0 & 0 \\
May & 26 & 144 & 111 & 132 & 112 & 132 & -6 & 0 & 0 \\
June & 61 & 189 & 55 & 127 & 100 & 106 & -66 & 0 & 0 \\
July & 1 & 152 & 34 & 159 & 114 & 123 & -158 & 0 & -61 \\
August & 0 & 34 & 166 & 203 & 127 & 121 & -203 & 0 & 0 \\
September & 58 & 173 & 282 & 212 & 140 & 119 & -154 & 0 & 0 \\
October & 9 & 160 & 72 & 196 & 151 & 122 & -187 & 0 & 0 \\
November & 79 & 138 & 159 & 147 & 116 & 143 & -68 & 0 & 0 \\
December & 316 & 205 & 280 & 147 & 108 & 120 & 0 & 0 & 0 \\
\hline Total & 2028 & 2543 & 2449 & 1873 & 1501 & 1456 & -842 & 0 & -61 \\
\hline
\end{tabular}

Table 2. Granulometry and chemical analysis of the soil

\begin{tabular}{|l|c|c|c|}
\hline \multirow{2}{*}{ Granulometry } & \multicolumn{3}{|c|}{ Horizon } \\
\cline { 2 - 4 } Clay & $0-20 \mathrm{~cm}$ depth & $20-40 \mathrm{~cm}$ depth & $60-80 \mathrm{~cm}$ depth \\
\cline { 2 - 4 } Silt & & & \\
Sand & 6.6 & 17.9 & 28.0 \\
O. M. \% & 17.6 & 7.5 & 9.1 \\
C \% & 75.8 & 74.5 & 62.8 \\
N\% & 5.52 & 1.51 & 0.29 \\
C:N & 3.21 & 0.88 & 0.17 \\
Water PH & 2.22 & 0.74 & 0.17 \\
& 14.5 & 11.9 & 10.0 \\
Total P (ppm) & 5.8 & 5.6 & 5.4 \\
Olsen P (ppm) & 174.5 & 81.8 & 54.3 \\
Exchangeable bases (meq/100 g) & 20.3 & 6.8 & 4.1 \\
Ca & 1.00 & & \\
Mg & 0.48 & 0.37 & 0.04 \\
K & 0.14 & 0.24 & 0.09 \\
Na & 0.08 & 0.09 & 0.05 \\
H & 0.03 & 0.13 & 0.07 \\
Al & 0.35 & 0.06 & 0.07 \\
Mn & 0.01 & 1.14 & 1.06 \\
C.E.C. & 2.19 & 0.01 & 0.01 \\
S/T \% & 78 & 2.39 & 1.82 \\
O. M. & & 35 & 14 \\
\hline
\end{tabular}

O. M. : Organic Matter

C. E. C. : Cation Exchange Capacity

S/T : Saturation rate of exchangeable bases complex 
Table 3. Description of the treatments

\begin{tabular}{|c|c|c|}
\hline & Treatments & Number of studied trees \\
\hline $\mathrm{K} 0 \mathrm{Cl} 0$ & control, without chlorine and potassium & 5 \\
\hline $\mathrm{K} 0 \mathrm{Cl} 2$ & $\begin{array}{l}\text { without potassium } \\
2 \mathrm{~kg} \text { of } \mathrm{NaCl} / \mathrm{tree}^{-1} / \mathrm{year}^{-1}\end{array}$ & 5 \\
\hline $\mathrm{K} 2 \mathrm{Cl} 0$ & $\begin{array}{l}2 \mathrm{~kg} \text { of } \mathrm{K}_{2} \mathrm{SO}_{4} \text {, } \text { tree }^{-1} / \text { year }^{-1} \\
\text { without chlorine }\end{array}$ & 5 \\
\hline $\mathrm{K} 2 \mathrm{Cl} 2$ & $\begin{array}{l}2 \mathrm{~kg} \text { of } \mathrm{K}_{2} \mathrm{SO}_{4} / \text { tree }^{-1} / \text { year }^{-1} \\
2 \mathrm{~kg} \text { of } \mathrm{NaCl} / \text { tree }^{-1} / \text { year }^{-1}\end{array}$ & 5 \\
\hline
\end{tabular}

$\mathrm{Mg}$ was applied as dolomite to all treatments ( $1 \mathrm{~kg}$ of dolomite $\left./ \mathrm{tree}^{-1} / \mathrm{year}^{-1}\right)$

Table 4. Leaf analysis in percent dry matter

\begin{tabular}{|c|c|c|c|c|c|c|c|c|c|c|c|c|}
\hline & \multicolumn{4}{|c|}{1994} & \multicolumn{4}{|c|}{1995} & \multicolumn{4}{|c|}{1996} \\
\hline & $\mathrm{K}$ & $S$ & $\mathrm{Na}$ & $\mathrm{Cl}$ & $\mathrm{K}$ & $S$ & $\mathrm{Na}$ & $\mathrm{Cl}$ & $\mathrm{K}$ & $S$ & $\mathrm{Na}$ & $\mathrm{Cl}$ \\
\hline $\mathrm{K} 0 \mathrm{Cl} 0$ & 1.422 & 0.202 & 0.038 & 0.037 & 1.592 & 0.192 & 0.032 & 0.213 & 1.198 & 0.186 & 0.052 & 0.026 \\
\hline $\mathrm{K} 2 \mathrm{Cl} 0$ & 1.812 & 0.206 & 0.017 & 0.033 & 2.351 & 0.174 & 0.016 & 0.283 & 1.717 & 0.208 & 0.018 & 0.044 \\
\hline $\mathrm{K} 0 \mathrm{Cl} 2$ & 1.384 & 0.180 & 0.171 & 0.405 & 1.587 & 0.173 & 0.284 & 0.818 & 1.028 & 0.188 & 0.342 & 0.348 \\
\hline $\mathrm{K} 2 \mathrm{Cl} 2$ & 1.587 & 0.197 & 0.147 & 0.487 & 2.128 & 0.154 & 0.122 & 0.825 & 1.656 & 0.201 & 0.176 & 0.472 \\
\hline
\end{tabular}

Table 5. Length, maximum width and mean total area of the largest leaflet of the reference frond (July 1995)

\begin{tabular}{lccccc}
\hline & $\begin{array}{c}\text { K 2 Cl } \\
\mathbf{2}\end{array}$ & $\begin{array}{c}\text { K 0 Cl } \\
\mathbf{2}\end{array}$ & K 2 Cl 0 & K 0 Cl 0 & \\
\hline Length $^{\text {a }}$ & 115.5 & 107.4 & 109.4 & 111.8 & N \\
& & & & & S \\
Width $^{\text {a }}$ & 6.5 & 6.2 & 6.0 & 5.8 & N \\
& & & & & S \\
Area $^{\mathrm{b}}$ & $494.7 \mathrm{a}$ & $422.3 \mathrm{~b}$ & $418.6 \mathrm{~b}$ & $415.6 \mathrm{~b}$ & $*$ \\
\hline
\end{tabular}

NS denotes no significant differences, $*$ denotes significant differences at $\mathrm{P}<0.05$

${ }^{\mathrm{a}}$ Length and width expressed in $\mathrm{cm}$

${ }^{\mathrm{b}}$ Area expressed in $\mathrm{cm}^{2}$ 


\section{Estimating the area of a frond $A_{F}$}

Frond area was measured by the "Tailliez" method (Tailliez et al., 1992). The leaflet areas previously estimated were multiplied by the number of leaflets upstream of them, and were then added up. At a given moment $t$, this area is assumed to be representative of the area of the fronds making up a crown.

$$
\begin{gathered}
A_{F}=\left(n_{1} A_{11}+n_{2} A_{12}+\ldots n_{n} A_{\text {ln }}\right)_{\text {right }}+\left(n_{1} A_{11}+\right. \\
\left.n_{2} A_{12} \ldots n_{n} A_{l n}\right)_{l \text { left }}
\end{gathered}
$$

Estimating the area of a leaf crown and the leaf area index

To estimate the area of a leaf crown, the frond area previously estimated multiplied the number of green fronds in situ. Once the mean area of a leaf crown and the planting density were known, the leaf area index could be calculated.

\section{Results}

\section{Frond analysis during the study}

Concerning $\mathrm{K}$ leaf content, a significant positive effect of $\mathrm{K}_{2} \mathrm{SO}_{4}$ occurred every year, confirming the efficient absorption of $\mathrm{K}$ by coconut palms (Table 4). $\mathrm{NaCl}$ manuring has produced a depressive effect on the $\mathrm{K}$ content in 1994 and 1996. A significant effect of $\mathrm{K}_{2} \mathrm{SO}_{4}$ on $\mathrm{S}$ level occurred every year. The $\mathrm{S}$ content has not varied much year after year. Concerning $\mathrm{Na}$ content, a positive effect of $\mathrm{NaCl}$ existed every year whereas a depressive effect of $\mathrm{K}_{2} \mathrm{SO}_{4}$ occurred. A spectacular positive effect of $\mathrm{NaCl}$ on $\mathrm{Cl}$ level in the coconut fronds occurred. It confirmed the efficiency of $\mathrm{Cl}$ absorption.

\section{Description of the largest leaflet}

The total area of the largest leaflet was significantly greater in the chlorine and potassium treatment $(\mathrm{K} 2 \mathrm{Cl} 2)$, unlike length and largest width (Table 4). A statistical analysis of the exclusive action of each of the nutrients and of their possible synergy revealed that chlorine and potassium played a predominant role (Table 9).

\section{Description of the fronds}

In July 1995, each of the allometric criteria described in Table 6, was not significantly different. From March to November 1996, the total number of leaflets inserted on the rachis of the dry fronds collected was significantly larger in treatment $\mathrm{K} 2 \mathrm{Cl} 2$ (Table. 7). For this criterion, the effect of $\mathrm{Cl}$ and $\mathrm{K}-\mathrm{Cl}$ synergy were significant (Table 9). As time went by, in each of the treatments, the number of leaflets inserted was a stable criterion, which did not evolve significantly. On the other hand, the fronds were significantly longer in treatments $\mathrm{K} 2 \mathrm{Cl} 2$ and $\mathrm{K}$ $2 \mathrm{Cl} \mathrm{0}$. That was linked to a longer petiole in those two treatments due to a significant potassium effect. Frond sizes remained stable over the reference period.

\section{Overall description}

The stem height and diameter of the coconut palms were significantly lower in control treatment $\mathrm{K} 0 \mathrm{Cl} 0$ (Table 8) This was the result of a significant chlorine effect and $\mathrm{K}-\mathrm{Cl}$ synergy for height, along with significant and highly significant $\mathrm{K}$ and $\mathrm{Cl}$ effects, without interaction of the two nutrients, on coconut palm diameter (Table 9).

In July 1995, the number of green leaves was significantly larger in treatments $\mathrm{K} 2 \mathrm{Cl} 2, \mathrm{~K}$ $0 \mathrm{Cl} 2$ and $\mathrm{K} 2 \mathrm{Cl} 0$, with significant individual $\mathrm{K}$ and $\mathrm{Cl}$ effects. The estimated leaf crown area was then significantly greater in treatment $\mathrm{K} 2 \mathrm{Cl} 2$, with highly significant effects for both nutrients and significant synergy. A year later, in July 1996, the differences between each of the four treatments were significant for both the number of fronds and the estimated areas. The two nutrients had a highly significant independent effect on these criteria. A synergy effect of the two nutrients was also detectable. The number of fronds increased significantly over the reference 
period. In July 1995, the palms in treatment K 2 $\mathrm{Cl} 2$ had $24.5 \%$ more fronds than those in $\mathrm{K} 0 \mathrm{Cl}$ 0 . That difference increased as time went by. A year later, there were $53.6 \%$ more fronds (Table 8 ). The same applied for estimated leaf crown areas.

Over the reference period, the curves monitoring the number of functional fronds revealed two periods (Fig. 1). The first, from July to December 1995 corresponded to a significant increase in the number of functional fronds. The increase was then steady. Over the same period, the number of dry fronds remained low. A second period began in January 1996. The variation in the number of green fronds was not significant and not regular, right up to the end of the observation period. However, the coconut palms in the $\mathrm{K} 2 \mathrm{Cl} 2$ treatments bore significantly more functional fronds than the other three treatments. At the same time, the variation in the number of dry fronds became significant for all the treatments. Over the same period, new fronds opened. Monthly mean leaf emission, all treatments combined, was equal to 1.46 fronds/month (i.e. 17.5 fronds/year), without any significant difference linked to the type of treatment.

\section{Discussion}

The absorption of fertilizer was efficient in general way. The leaf analysis revealed yet an antagonism between $\mathrm{K}$ and $\mathrm{Na}$. In that case, reached $\mathrm{K}$ levels were not limiting compared to the usual treshold of $1.5 \%$ in leaf number 9 . The hypothesis of a possible role of accompanying ions i.e. $\mathrm{Na}$ for the $\mathrm{NaCl}$ fertilizer and $\mathrm{S}$ for the $\mathrm{K}_{2} \mathrm{SO}_{4}$ fertilizer could be put aside (Bonneau, 1998). The lack of $\mathrm{Na}$ effect has been demonstrated in Dabou in Côte d'Ivoire (Ollagnier and Ochs, 1971). About S, it has been demonstrated with other trials in Gunung Batin (Bonneau, 1998) that the increase of $S$ leaf content was not followed by additional growth and yield.
It appeared that potassium alone had a significant positive effect (Table 5) on certain morphological criteria. It acted on leaflet area and highly significantly on frond size, by increasing petiole length, hence logically the total frond length. On the other hand, its effect on the mean number of fronds per crown and the frond area was comparable to that of chlorine.

Chlorine had long been disparaged for plant mineral nutrition. The literature often reported numerous cases of toxicity, rarely the opposite (Braconnier, 1988). Our study corroborates the experimental studies of chlorine on betel palm yields and shows the truly positive action of chlorine on the great majority of targeted morphological criteria.

Concerning the leaflets, chlorine acted on their mean number, which was significantly larger as soon as chlorine was applied, on their maximum width, and on their total area, which increased significantly. According to Halstead (1992), chlorine played a significant role in cell division, increasing it; the leaflets in the chlorine treatments would therefore seem to have a larger number of cells. In addition, Braconnier et al. (1989) and Halstead (1992) emphasized cell size, showing that high chlorine concentrations in the tissues enabled more effective osmotic adjustment, maintaining cell turgor efficient during dry periods.

Concerning the fronds, no significant treatment effect was found in July 1995. On the contrary, from March to November 1996, K 2 Cl 2 and $\mathrm{K} 2 \mathrm{Cl} 0$ had a significant effect on the total length of collected dry fronds, due to an increase in the petiole length. In order to explain these results, under optimum growing conditions, $3 \frac{1}{2}$ to 4 years passed between the initiation of the leaf primordium and frond death (Menon et al., 1958). During the maturation phase stretching over around 2 years, fronds that are at the stage of a primordium more or less differentiated at the apex are particularly susceptible to environmental conditions. 
Table 6. Total mean number of leaflets inserted and green frond sizes (July 1995)

\begin{tabular}{lcccccc}
\hline & $\mathrm{K} \mathrm{2} \mathrm{Cl} \mathrm{2}$ & $\mathrm{K} \mathrm{0} \mathrm{Cl} \mathrm{2}$ & K 2 Cl 0 & K 0 Cl 0 & \\
\hline Number of leaflets & 220.0 & 208.8 & 216.4 & 214.6 & NS \\
\hline Length $^{\text {a }}$ & of petiole & 137.2 & 133.4 & 123.4 & 124.8 & NS \\
& of rachis & 397.2 & 362.6 & 359.0 & 371.6 & NS \\
& Total & 534.4 & 496.0 & 482.4 & 496.4 & NS \\
\hline Total area $^{\mathrm{b}}$ & & 6.9 & 5.8 & 6.0 & 6.1 & NS \\
\hline
\end{tabular}

NS denotes non-significant differences

${ }^{\text {a }}$ Length expressed in $\mathrm{cm}$

${ }^{\mathrm{b}}$ Area expressed in $\mathrm{m}^{2}$

Table 7. Total mean number of leaflets and dry frond sizes (March to November 1996)

\begin{tabular}{lcccccc}
\hline & $\mathrm{K} \mathrm{2} \mathrm{Cl} \mathrm{2}$ & $\mathrm{K} \mathrm{0} \mathrm{Cl} \mathrm{2}$ & $\mathrm{K} \mathrm{2} \mathrm{Cl} \mathrm{0}$ & $\mathrm{K} \mathrm{0} \mathrm{Cl} \mathrm{0}$ & \\
\hline Number of leaflets & $221.3 \mathrm{a}$ & $215.2 \mathrm{~b}$ & $214.5 \mathrm{~b}$ & $211.0 \mathrm{~b}$ & $* *$ \\
\hline Length $^{\mathrm{a}}$ & of petiole & $144.4 \mathrm{a}$ & $134.2 \mathrm{~b}$ & $146.0 \mathrm{a}$ & $131.4 \mathrm{~b}$ & $* * *$ \\
& of rachis & 361.9 & 361.2 & 365.8 & 353.8 & $\mathrm{NS}$ \\
& Total & $506.4 \mathrm{a}$ & $495.4 \mathrm{~b}$ & $511.8 \mathrm{a}$ & $485.2 \mathrm{~b}$ & $* * *$ \\
\hline
\end{tabular}

NS denotes non-significant differences, ${ }^{* *}$ denotes significant differences at $\mathrm{P}<0.01, * * *$ at $\mathrm{P}<0.001$

${ }^{\mathrm{a}}$ Length expressed in $\mathrm{cm}$

Table 8. Description of the coconut palms - July 1995 and 1996 (area expressed in $\mathrm{m}^{2}$ )

\begin{tabular}{|c|c|c|c|c|c|}
\hline & $\mathrm{K} 2 \mathrm{Cl} 2$ & $\mathrm{~K} 0 \mathrm{Cl} 2$ & $\mathrm{~K} 2 \mathrm{ClO}$ & $\mathrm{KOClO}$ & \\
\hline Stem height in July 1995 (in cm) & $247.5 \mathrm{a}$ & $261.7 \mathrm{a}$ & $254.1 \mathrm{a}$ & $197.4 \mathrm{~b}$ & $* * *$ \\
\hline Stem diameter in July 1995 (in cm) & $28.0 \mathrm{a}$ & $27.2 \mathrm{a}$ & $26.6 \mathrm{a}$ & $24.7 \mathrm{~b}$ & $* * *$ \\
\hline Number of green fronds in July 1995 & $18.8 \mathrm{a}\left(+24.5 \%{ }^{\mathrm{a}}\right)$ & $17.2 \mathrm{a}$ & $17.7 \mathrm{a}$ & $15.1 \mathrm{~b}$ & *** \\
\hline Number of green fronds in July 1996 & $29.8 \mathrm{a}(+53.6 \%)$ & $27.4 \mathrm{~b}$ & $23.6 \mathrm{c}$ & $19.4 \mathrm{~d}$ & $* * *$ \\
\hline Crown leaf area in July 1995 (in m²) & $130.3 \mathrm{a}(+41.6 \%)$ & $99.7 \mathrm{~b}$ & $106.6 \mathrm{~b}$ & $92.0 \mathrm{~b}$ & $* * *$ \\
\hline Crown leaf area in July 1996 (in m²) & $206.2 \mathrm{a}(+74.1 \%)$ & $159.0 \mathrm{~b}$ & $141.7 \mathrm{c}$ & $118.4 \mathrm{~d}$ & $* * *$ \\
\hline LAI $^{\mathrm{b}, \mathrm{c}}$ in July 1995 & 2.1 & 1.6 & 1.7 & 1.5 & \\
\hline LAI in July 1996 & 3.3 & 2.5 & 2.3 & 1.9 & \\
\hline
\end{tabular}

*** Denotes significant differences at $\mathrm{P}<0.001$

${ }^{a}$ The fronds percentage is calculated in relation to the control treatment $\mathrm{K} 0 \mathrm{Cl} 0$

${ }^{\mathrm{b}} \mathrm{LAI}=$ Leaf Area Index

${ }^{c}$ After the drought the coconut palms death is low in the trial. So the LAI has been calculated with a homogeneous planting density of 160 trees/ha 
The fronds sampled in July 1995 were still functional and were initiated approximately in July 1992. The fronds sampled from March to November 1996 were dry. Thus, according to Menon et al. (1958), they were initiated 4 years earlier, i.e. between March and November 1992. In both cases, these fronds were initiated during the 1992 low dry season. In the second case, treatments $\mathrm{K} 2 \mathrm{Cl} 2$ and $\mathrm{K} 2 \mathrm{Cl} 0$ buffered these effects, making it possible to maintain significantly greater sizes compared to those of the control (Table 4). However, that was not the case with the fronds sampled in July 1995 (Table 3 ) though the same trend was seen. It is plausible that the small number of functional fronds sampled (5 fronds/treatment) is the main cause behind the lack of significant difference in the results. Petiole and rachis lengths and the total length of the fronds, were stable vegetative criteria that did not evolve over the reference period. More numerous leaflets with a larger area should be reflected in a larger frond area in the chlorine and potassium treatment, whereas statistically, that was not the case. The small sample size could be the reason. Nevertheless, a trend did occur, indicating that the fronds in treatment $\mathrm{K} 2 \mathrm{Cl} 2$ had a larger area (Table 5).

Concerning the entire plant, the palms receiving chlorine revealed greater vigor, proving that chlorine has an undeniable effect, and much greater than potassium would have at this level. That was reflected in significantly taller and thicker stems. Bonneau (1998) emphasized that Tall type coconut palms usually resist water stress much better than Dwarf type palms; he reported that there was probably a cause and effect relationship for Tall palms, generally with greater vertical stem development and a larger bole. Studies carried out on other kinds of palms have emphasized the potential role of the stem in cases of resistance and water savings. In oil palm, Adjahossou (1983) showed that the bole, which is acknowledged as being a storage organ containing carbohydrate reserves, would seem, during dry seasons, to be the site of substantial hydrolase activities that break down the stored carbohydrates into soluble sugars, which then replace photosynthesis carbohydrates whose production is then apparently substantially reduced. Bonneau (1998) showed that the stem plays a role in water transportation, but also in ballasting and balancing, depending on the evaporative demand in the leaf organs. The existence of a highly developed parenchyma, a highly hydrated medium, backs up this hypothesis. In the coconut palms that received chlorine, the leaf crown was more voluminous and maintained a high mean number of functional fronds. Furthermore, the mean area of those crowns was significantly greater. Coconut palms adapt to limiting or highly limiting water supply conditions by reducing their transpiration surface; the number of functional fronds markedly decreases. That is seen in all cases, even in coconut palms receiving chlorine. In July 1995, the mean number of functional fronds was 18.8 in treatment $\mathrm{K} 2 \mathrm{Cl} 2$. It is usually from 30 to 35 green fronds per palm in a situation of equilibrium (Bonneau, 1998). However, although that level was well below than for normal conditions even several months after the water deficit had been removed, there were still $24.5 \%$ more fronds than in the controls. This phenomenon increased over time; indeed, a year later, in July 1996, those same coconut palms had $53.6 \%$ (average) more functional fronds. Whilst over the same period, the new frond emergence rate remained stable, at 1.46 fronds/month over the entire observation period. These results need to be seen in relation to the variation in the number of dry fronds, which increased highly significantly in the treatments without chlorine from December 1995 (Fig. 1). Here again, both chlorine and potassium kept the fronds in a functional state for longer. Nevertheless, the "convalescence" phase that followed the drought period was not shortened in the chlorine and potassium treatments. That phase ended a year after the water deficit was removed. In a situation of equilibrium, the coconut palms in treatment $\mathrm{K}$ $2 \mathrm{Cl} 2$ had a higher mean leaf area and, on a plot scale, a higher leaf area index, suggesting they would start bearing earlier. That was seen in all the chlorine nutrition trials at the plantation. Moreover, Ohler (1984) showed that these parameters were significantly correlated to nut harvests. 
Table 9. Potassium and chlorine effects on coconut parameters and their interaction at different levels

\begin{tabular}{|c|c|c|c|c|c|}
\hline & & & Effect of $\mathrm{K}^{+}$ & Effect of $\mathrm{Cl}$ & Interaction $\mathrm{K}^{+} / \mathrm{Cl}$ \\
\hline \multirow[t]{8}{*}{ Organ } & \multirow[t]{3}{*}{ Leaflet } & Length & NS & NS & NS \\
\hline & & Maximum width & NS & NS & NS \\
\hline & & Area $^{a}$ & * & $*$ & NS \\
\hline & \multirow[t]{5}{*}{ Frond } & Number of leaflets & NS & ** & ** \\
\hline & & Length of petiole & **** & NS & NS \\
\hline & & Length of rachis & NS & NS & NS \\
\hline & & Total length & **** & NS & NS \\
\hline & & Area & NS & NS & NS \\
\hline \multirow[t]{6}{*}{ Plant } & \multirow[t]{2}{*}{ Stem } & Heigth & NS & * & ** \\
\hline & & Diameter & * & **** & NS \\
\hline & \multirow[t]{4}{*}{ Leaf Crown } & Number of fronds & & & \\
\hline & & In July 1995 & ** & * & NS \\
\hline & & In July 1996 & **** & **** & NS \\
\hline & & Leaf crown area & **** & **** & $*$ \\
\hline
\end{tabular}

$*$ Denotes significant differences at $\mathrm{P}<0.05, * *$ at $\mathrm{P}<0.01$, *** at $\mathrm{P}<0.001$, NS non-significant differences; ${ }^{\text {a }}$ Estimated parameters
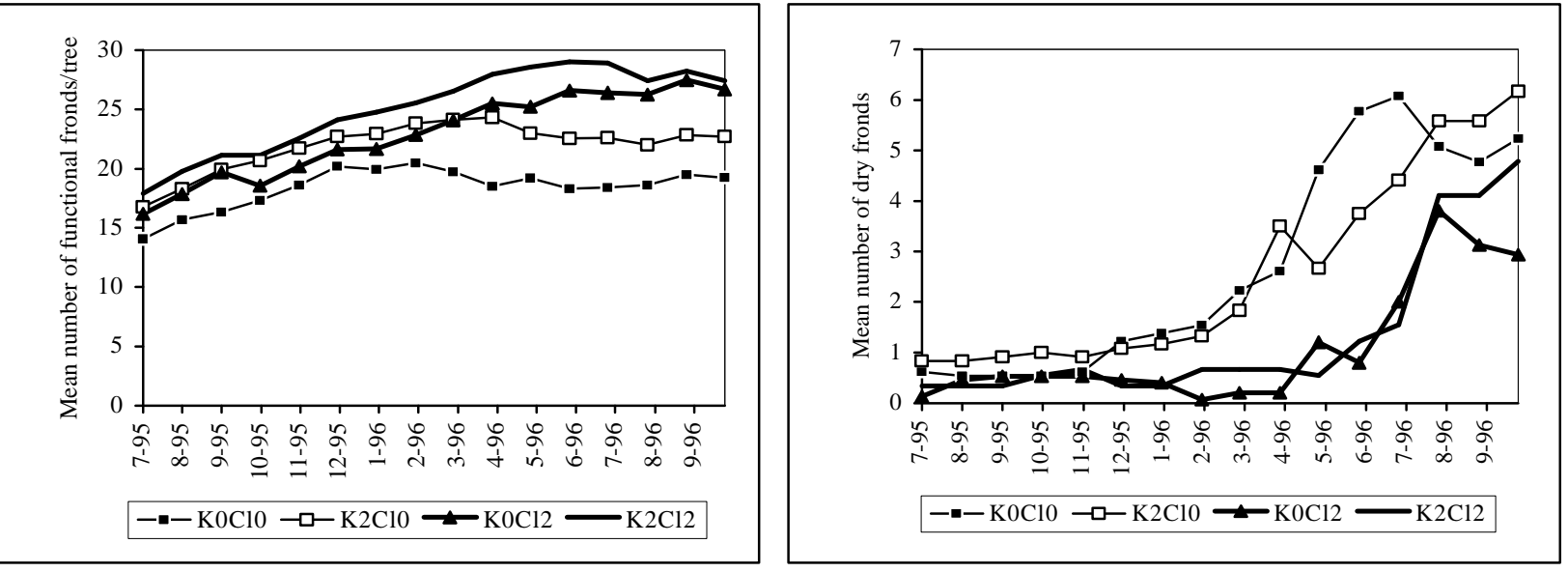

Figure 1. Variation in the number of fungtional fronds (leaft) and dry fronds (right) 


\section{Acknowledgement}

The authors would like to thank PT. MultiAgro Corporation management for their logistics and technical back-up, without which this study could not have been undertaken, along with Messrs Y. Caraglio (CIRAD/AMIS), J.L. Jacob (CIRAD/AMIS), and O. Roupsard (CIRAD/CP) for their relevant comments intended to improve this publication.

\section{References}

Adjahossou, F. 1983. Contribution à l'étude de la résistance à la sécheresse chez le palmier à huile (Elaeis guineensis Jacq.), thèse, Université de Paris VII, 203 pp.

Bonneau, X. 1998. Recherches sur les facteurs limitant la production végétale en conditions de stress hydrique. Cas du cocotier à Gunung Batin (Indonésie): Rôles du chlore dans l'économie de l'eau, thèse, Institut Nationale Agronomique de Paris - Grignon, 195 pp.

Braconnier, S. 1988. Physiologie de la nutrition en chlorure chez le palmier à huile et le cocotier. Thesis. Université des sciences et techniques du languedoc, Montpellier, 207 pp.

Braconnier, S. and d'Auzac, J. 1989. Effet d'une carence en chlorure au champ chez le cocotier hybride PB 121. Oléagineux 44: 467-474.
Halstead, E. H., Beaton, J. D., Keng, J. C. W. and Miaoyuan, W. 1992. Chloride: new understanding of this important plant nutrient. S.J.. USA, pp. 314-325.

Menon, K. P. V. and Pandalai, K. M. 1958. The Coconut Palm, a Monograph. Indian Central Coconut Committee, Ernakulam, Kerala, India, $384 \mathrm{pp}$.

Nucé de Lamothe de M. and Bénard, G. 1985. L'hybride de cocotier PB 121 (ou Mawa) $(\mathrm{NJM} \times \mathrm{GOA})$. Oléagineux 40: 261-265.

Ohler, J. G. 1984. Coconut, Tree of Life. Plant production and protection paper. FAO, Rome, 446 pp.

Ollagnier, M. 1985. Réaction ioniques et conduite de la fertilisation en liaison avec la résistance à la sécheresse des oléagineux pérennes (palmier à huile et cocotier). Oléagineux 40: 1-10.

Ollagnier, M. and Ochs, R. 1971. La nutrition en chlore du palmier à huile et du cocotier. Oléagineux 6: 367-372.

Tailliez, B. and Ballo Koffi C. 1992. Une méthode de mesure de la surface foliaire du palmier à huile. Oléagineux 47: 537-539. 